Sign Systems Studies 49(1/2), 2021, 191-215

\title{
Trajectories of anticipation: Preconceptuality and the task of reading habit
}

\author{
Sebastian Feil ${ }^{1}$
}

\begin{abstract}
The article characterizes Peirce's concept of habit as a major contribution to a Peircean concept of preconceptuality, first, in relation to its function in the sign process, and second, in relation to other concepts of preconceptuality in cultural studies. Hans-Georg Gadamer's notion of prejudice, Michel Foucault's notions of the preconceptual and the dispositif, and Hans Blumenberg's conception of metaphor all share certain key characteristics with Peirce's notion of habit. The same comparison also highlights the fact that certain elements are missing from the current discourse on Peirce's notion of habit: although any rendition of the concept of habit itself implicitly relies on a theory of historicity and of rule-association, these aspects only emerge explicitly in comparison with theories that more explicitly focus on such aspects.

Another question raised in the context of such a comparison is the relevance of habit for theories of conceptuality. Peirce claims that descriptions of concepts are best realized through the description of the habits involved in them. A major part of a concept's coordinative power lies with the habits associated with the concept. However, no systematic inquiry into the possibility of rendering actual habits more definitive in comprehension has been undertaken. An attempt is therefore made to remedy that situation by elaborating on those aspects of Peirce's theory of habit relevant to a theory of "reading" habit, and to sketch an outline of such a theory.
\end{abstract}

Keywords: Peirce; habit; preconceptuality; prejudice; metaphor; history

\section{Introduction}

Regarding the question as to which semiotic concepts best represent the effectiveness of anticipation in sign use, Peirce's concept of habit is a strong contender for the first place. Habit is the interface where Peirce's theory of semiotics and pragmatism come together: it represents the possibility of conceptual guidance as well as the terminus of sign-action in successful practical adaptation of meaning.

1 Chair of Comparative Literature, University of Augsburg, Universitätsstraße 10, 85159 Augsburg, Germany; e-mail: sebastian.johann.feil@gmail.com. 
So far, extensive attention has been paid to the ways in which habit relates to other elements of Peirce's semiotics. In this regard, Donna West's and Myrdene Anderson's volume Consensus on Peirce's Concept of Habit (2016) is a major landmark in the elucidation of the concept. Numerous contributions provide more and more intricate ways of describing the inner workings of the sign process in relation to habit. However, only a few inquire more deeply into the relation of Peirce's concept of habit to other "anticipatory" concepts (Cannizzaro, Anderson 2016 and Bisanz, Cunningham 2016 being two of the more recent exceptions to that rule). And even fewer seem to be asking the question that seems most pressing from the point of view of the theory of meaning: is habit indeed a major factor in the guidance of symbolic life? And is the production of meaning as a whole substantially dependent on habit? Is it not inevitable, then, that at some point we not only reach a consensus on how habit works, but also on how particular habits actually in operation at any given time can be described in such a way that we understand how meaning can be described not only as semantically discrete, but in relation to the vast field of prior experience active in the formation of any habit?

The aim of this paper is twofold. Firstly, Section 3 is dedicated to a comparison between Peirce's notion of habit and other ideas involving the prefiguration of linguistic and extra-linguistic meaning. The choice of "other ideas" is focussed more specifically on theories of preconceptuality and is limited to theories that share with Peirce a strong commitment to a critique of Cartesian rationalism as the basis of a modern rejection of preconceptuality. What is included is, therefore, HansGeorg Gadamer's hermeneutical notion of prejudice, Foucault's evolving notion of the preconceptual as dispositif and Hans Blumenberg's metaphorology. Secondly, Section 4 elaborates more fully on some aspects of Peirce's concept of habit relevant to the question of "reading" habit by building on some key ideas revolving around the notion of preconceptuality which have been generated through the cross-fertilization in the preceding comparison.

In order to be able to limit productively the scope of aspects of Peirce's concept of habit relevant to the overall discussion, a short summary of these aspects precedes Sections 3 and 4 - the main sections of the paper.

\section{Peirce's semiotic notion of habit}

The concept of habit finds its way into Peirce's writing in the prime of his rather explicit anti-Cartesianism. Descartes, in his Discours de la méthode, recounts his four precepts for "good conduct in reasoning", enveloped in a recollection of his past scientific successes. The first rule is: 
[...] never to accept anything as true that I did not incontrovertibly know to be so; that is to say, carefully to avoid both prejudice and premature conclusions; and to include nothing in my judgements other than that which presented itself to my mind so clearly and distinctly, that I would have no occasion to doubt it. (Descartes 2006[1637]: 17)

Almost from the outset of his philosophical career, Peirce was strongly opposed to the idea that there could be any type of cognition completely devoid of all prejudice, "for [prejudices] are things which it does not occur to us can be questioned" (W2: 212). In his view, the reason for this is that any cognition is necessarily determined by previous cognitions, without any definitive beginning (cf. W2: 213).

Nine years later, in 1877, Peirce was convinced that there was an essential relation between what anyone believes and the habits that person holds. In "The fixation of belief" (one of the Popular Science Monthly papers, W3: 242-257), Peirce links the attainment of belief to the formation of habit. This entails the possibility that habits are fixtures of knowledge as well as a pre-given of further knowledge, without denying that they are in fact open to change and manipulation. Peirce, while very much aware of the psychology of habit of the time, distinguishes himself from a strictly psychological view of habit and gives the concept, as it were, a logical spin (Feodorov 2017). The preference for a predominantly logical understanding of habit manifests itself quite overtly in the way Peirce associates habit formation (essentially, the formation of general rules within the organism) with the inductive mode of inference (e.g. in W2: 232-3; W3: 337; W8: 151). This is not unlike the way in which, for example, Wilhelm Dilthey (2002[1910]: 154-5) conceived of the "generalization" of "life experience". However, already at this early stage in the development of the concept (and differently from Dilthey and his framework of Geisteswissenschaften) Peirce thought that the activation of habit, i.e. the way in which it becomes "suggestible by sensations" (W8: 151), is not solely the analysis of some a priori predicate contained in the rule. Prescriptions for thought and action are inferred from the rule involved in a habit but come to effect, first and foremost, through a "psychical process having the form of hypothetic inference" (W8: 151).

After returning to the concept of habit and its relation to his semiotics on several occasions (cf. Nöth 2016), in 1907 Peirce made his last concentrated effort to explain his pragmatism and properly integrate it into his semiotics, which, at this point, had become a universal theory of relations. The key move in this attempt (which variously goes under the title "Pragmatism" or by its manuscript number 318 ) was to explain the interpretant sign in terms of practical effects. 
These 'practical interpretants' 2 are organized according to the mode of practical response $v i s-\grave{a}-v i s$ a sign-object relation. Peirce distinguishes between emotional, active and conceptual response and calls the corresponding signs "emotional", "energetic" and "logical interpretant" (EP2: 409). They are continuously linked (i.e. emotional response and active response are contained in the conceptual response) and are not identical with the immediate, dynamical or final interpretant from 1906 (CP 4.536). Instead, they are either an aspect of a subdivision of all three earlier conceptions of the interpretant (Short 2007: 57-59; Santaella 2016: 162-3) or the dynamical interpretant - an actually performed interpretation (Lalor 1997). Given how closely Peirce's idea of the degrees of practical response in sign processes is linked to the idea of the possibility of controlling infinite semiosis (cf. Short 2007: 59), this matter is of universal importance for semiotics. Moreover, 'habit' is the key Peircean term that at once covers the entire range of "conventionalized" meaning but also adds to the theory of 'conventionality' several distinct characteristics (Nöth 2010).

The argument here, however, is mainly concerned with the fact that the entire conception of practical responses would not be complete without reference to an auxiliary conception variously referred to by Peirce as the "Final Logical", "Ultimate Logical" or "Ultimate Intellectual" Interpretant (EP2: 418, 419, 430, respectively). This variant nomenclature informs us about the central idea behind this concept, its intended designation of something akin to a definitive effect that cannot be honed any further:

It is evident that a definition, even if it be imperfect owing to vagueness, is an intellectual interpretant of the term it defines. But it is equally evident that it cannot be the ultimate intellectual interpretant, inasmuch as it is itself a sign, and a sign of the kind that has itself an intellectual interpretant, which is thereby an intellectual interpretant of the term defined. This consideration compels us to seek elsewhere than among signs, or among concepts, since they are all signs, for ultimate intellectual interpretants. This same consideration cuts off from searching among desires, expectations, etc., for ultimate intellectual interpretants, since such intellectual character as desires, etc., possess is due solely to their referring to concepts. At the same time, the ultimate intellectual interpretants must be some kind of mental effects of the signs they interpret. Now after an examination of all varieties of mental phenomena, the only ones I have been able to find that possess the requisite generality to interpret concepts and which fulfill the other conditions are habits. (EP2: 431)

2 Peirce earlier called a very close variation of these the "responsive interpretant" (NEM4: 317). 
Definitions, being conceptual responses, are, according to Peirce, limited to the realm of semiotic referentiality and thus have no characters capable of limiting and thus anchoring semiosis. Likewise, emotional stimuli for action, like desire, are naturally cut off from providing grounds for intellectual closure, since they are merely coordinative of action in relation to concepts themselves. Habit, however, is capable of providing guidance across the entire spectrum of possible practical responses. According to Mats Bergman (2016: 171), the basic outlook that final/ultimate logical interpretant should be narrowed down to habit is "widely accepted". Hence, Bergman devotes an interesting article to exploring the consequent possibility that (1) "Peirce's pragmatic account of the interpretant surpasses that of mere explication of habitual meaning" (Bergman 2016: 173) and that (2) the pragmatic method ("consider what effects...", W3: 266) is therefore capable not only of ascertaining meaning, but also that "its animating goal is the controlled improvement of our symbolic habits" (Bergman 2016: 185). Such a conception of 'conceptual meliorism' (see also Bergman 2012) is easy to accept, especially since its weak version - that habits do change according to circumstance (usually not at once, but after some pressure has been applied) - is quite uncontroversial. The problem posed by this weak version is of course that any uncontrolled modification of a symbol, concept or habit may lead to improvement as well as deterioration. Thus, Bergman explicitly follows one particular trail of inquiry outlined by Peirce. In conjunction with the pragmatic maxim, and as far as 'habit-change' is concerned, Peirce wanted to restrict the final logical interpretant (the "living definition") to the "deliberately formed, self-analyzing habit" (EP2: 418). Peirce explicated 'self-analysing' as "formed by the aid of analysis of the exercises that nourished it" (EP2: 418), and the implication is clear: in order to attain better concepts, one has to improve one's final logical interpretants, i.e. one's habits. This, however, raises an important issue. If the ultimate aim of a pragmatistically oriented semiotics is also to present a model for the modification of pre-existing habits, then such a model needs to incorporate a method for the identification of habits. Change, so to speak, requires anticipation. Such a method has clearly been a pragmatistic desideratum from the beginning, as is evident in a footnote Peirce appended to the paragraph of the final "Pragmatism" draft quoted above:

Meaning of a general physical predicate consists in the conception of the habit of its subject that it implies.

And such must be the meaning of a psychical predicate.

The habits must be known by experience which however exhibits singulars only.

Our minds must generalize these.

How is this to be done? (EP2: 550) 
The fact that there is only a rough draft of an answer to this central methodological question in an earlier draft of the "Pragmatism" manuscript ${ }^{3}$ is, in my opinion, a challenge that needs to be faced, especially when one believes that working on a truly interdisciplinary commens (or "Communicational Interpretant", cf. EP2: 478) for the interpretation of life and culture is indeed one of the primary tasks of semiotics in general. The lack thereof becomes especially evident when looking at other conceptions of conceptual guidance that have developed in the various areas of hermeneutics and conceptual history in the continental tradition, where semiotics often plays only a minor role, but has a great potential for inserting itself in these discourses in convincing ways. The following section is thus dedicated to exploring the relationship between Peirce's notion of habit and three prominent models of conceptual conditionality present in continental thought.

\section{Habit in comparison}

It is difficult to say whether Peirce ever directly associated the concepts of prejudice (as employed by Descartes) and habit. Both concepts, however, share a systemic function in the context of his discussions of the "normative sciences" and especially "logic" (EP2: 60), which highlights a striking similarity between the two concepts. The main point of comparison between these terms is that both 'prejudice' and 'habit' (as well as a few somewhat singular variants like "preconceived notion" in EP2: 81-84, 114) ${ }^{4}$ refer to a collectively distributed structure - neither immediately clear nor uncontroversially distinct - that contributes to the prefiguration of understanding within the individual. The choice of 'habit' over 'prejudice' for the comparative purpose of this paper is legitimate for two reasons: first, habit entails 'preconceptuality' in the broadest sense possible, describing pre-intentional phenomena across the entire biosphere - from regular energy discharges in the individual cell (W6: 191) to human intellectual history of and beyond entire epochs - as "links in forming the endless chain of humanity" (Dewey 2008[1922]: 19). Second, habit, as we have seen, is the particular term that Peirce did indeed deem important enough to be discussed in conjunction with his comprehensive semiotic theory. There, as we have also seen, some form of preconceptuality quite

3 The third draft, composed a few months before the fifth and final one, see, e.g., the introductory notes in EP2: 398.

4 Among other things, the term 'preconceived notion' is also representative of Peirce's conceptual meliorism. He explicitly insisted that one major benefit of learning about history is to overcome one's 'preconceived notions' (EP2: 83-84; see Feil, Olteanu 2018 on some of the consequences arising from this view). 
explicitly covers the entire range of practical activity, from emotional to logical response, from 'tenacity' via 'authority' and 'fashion' all the way to 'science' (W2: 254).

The aim now is to show how semiotics integrates with other approaches to preconceptual guidance. In general, the argument rests on the notion that any theory of preconceptuality is conditional on some form of anti-Cartesian stance. This is in line with Peirce's idea already indicated above that cognition in general is always the result of previous cognitions, that any thought is always preceded by something which cannot be eliminated because it is already fundamental to the realization of that same thought.

Choosing 'habit' has less to do with being biased towards a particular theory and more with the simple fact that (1) we are looking for a semiotic theory to integrate as many specific theories of preconceptuality as possible, and that (2) Peirce offers a semiotic theory with a notion of preconceptuality already included. The aim is thus not to establish any form of hierarchy between different concepts and approaches but simply to rely on the most general concept available to semiotics. The positions compared are often portrayed as ideologically conflicting. If nothing else, the merit of comparing these different approaches from a more general vantage point shows that such conflicts are avoidable. Moreover, such a comparison will reveal a number of things which have previously not been considered with regard to the nature of habit itself.

\subsection{Gadamer: preconceptuality through history}

The first of the three anti-Cartesians discussed is Hans-Georg Gadamer, whose conceptions of 'tradition' and especially 'prejudice' have left an indelible mark on phenomenological hermeneutics in general (cf. e.g. Fehér 2016). Consider this famous paragraph from his major book Truth and Method, in which he links individual 'prejudice' to collective practice, and which precisely addresses those practical entanglements of subjectivity existing as precursors to reflexive habit-change:

Long before we understand ourselves through the process of self-examination, we understand ourselves in a self-evident way in the family, society, and state in which we live. The focus of subjectivity is a distorting mirror. The self-awareness of the individual is only a flickering in the closed circuits of historical life. That is why the prejudices of the individual, far more than his judgments, constitute the historical reality of his being. (Gadamer 2013[1960]: 289) 
Against the backdrop of a naive form of rationalism, Gadamer's hermeneutics conceives of subjectivity as essentially premodified by collectivity - and collectivity by history. This form of contextual objectivism is comparable to Peirce's conviction that signification stands on its own and "that neither an utterer, nor even, perhaps, an interpreter is essential to a sign" (EP2: 404), at least insofar as both views preclude psychology from being fundamental for understanding. 'Prejudice' is supposed to play a quintessential role insofar as it is constitutive for any type of understanding whatsoever. Thus, in Truth and Method, in the well-known chapter on "Elements of a theory of hermeneutic experience", Gadamer (2013[1960]: 283) writes:

The recognition that all understanding inevitably involves some prejudice gives the hermeneutical problem its real thrust. In light of this insight it appears that historicism, despite its critique of rationalism and of natural law philosophy, is based on the modern Enlightenment and unwittingly shares its prejudices. And there is one prejudice of the Enlightenment that defines its essence: the fundamental prejudice of the Enlightenment is the prejudice against prejudice itself, which denies tradition its power.

The 19th-century historicists mentioned here argued that pure Cartesian rationalism as well as scientistic naturalistic reduction do not do justice to what they consider the prime agent of humanity, that is, history. Gadamer, however, asserts that historicism's belief, while correct in its assessment, is misguided insofar as it sustains the idea that prejudice can be transcended eventually (Odenstedt 2003). This, Gadamer argues, contradicts the essential connection between history and prejudice. And it is at this stage of the argument that Gadamer himself feels comfortable enough to make actually explicit a clearly delimited prejudice, something that he will, in the course of Truth and Method, deny ever being fully possible. Understanding is patently "not a method which the inquiring consciousness applies to an object it chooses and so turns it into objective knowledge", but "an event, and the task of hermeneutics, seen philosophically, consists in asking what kind of understanding, what kind of science it is, that is itself advanced by historical change" (Gadamer 2013 [1960]: 320). Gadamer's hermeneutics thus argues for the necessity to accept the preconceptual but gives us no methodological clues apart from submitting oneself to the eventuality of tradition.

Nevertheless, while strongly overemphasizing the impossibility of arriving at secure knowledge, Gadamer's insistence on the need always to monitor one's prejudices is of some value. No single cognitive position is ever entirely pre-theoretical (i.e. intuitive). This does not mean, however, that every position is fundamentally flawed, but simply that every position rests on preconceptions. 
Moreover, a point can be made in favour of Gadamer's assessment of understanding as an event. Events and their constitutive action can certainly be described. And the focal point of action is, as Peirce put it, habit. There is thus a fundamental compatibility between Gadamerian hermeneutics and Peircean pragmatist semiotics. The sole point of divergence is a difference in the assessment of the possibility of habit-change: Gadamer's concept of 'prejudice-change' is, at best, limited to random changes in tradition. The general phenomenological metaphor of a perpetually elusive 'horizon', to which Gadamer (e.g. 2013[1960]: 246) subscribes, is thus very apt, if perhaps unintentionally so. Submission to prejudice, in Gadamer's hermeneutics, is the result of such a figuration of finality as "unreachable". Peirce, on the other hand, is able to assert an element of reflexivity vis-à-vis the 'ultimate intellectual interpretant' precisely because the conception of finality contained in his concept of habit is fundamentally procedural.

Nevertheless, Gadamer also adds one important element to a general conception of preconceptuality, which is only implicit in Peirce's account, namely history. In the same way that prejudice is an intersubjective effect resulting from processes that predate the subjective present, habit-formation and habit-change typically do not happen instantaneously but after a series of inductions performed on similar events over time. One merit of this comparison for semiotics in general is that it shows that sign processes, in so far as they are guided by habit, require models that incorporate an element of diachronic analysis tailored to the explication of the preconceptual.

\subsection{Foucault: preconceptuality through power}

Michael Foucault, anti-Cartesian by way of being a strong anti-subjectivist, has for decades been a fixture in continental thought as a philosopher of history who went, as Hubert Dreyfus and Paul Rabinow (1983) put it, "beyond hermeneutics and structuralism". The reason for including Foucault in this comparison is thus to see how his engagement with the possible depth and orderliness of meaning fares in comparison to a general semiotic perspective on meaning as habit.

Dealing with the formation and functions of what Foucault calls 'discourse' in The Archaeology of Knowledge, he also dedicates a chapter to the formation of concepts. At the centre of this discussion is the idea of a 'pre-conceptual' (préconceptuel) level, on which alternative and even contradictory "concepts can coexist" next to each other through "the rules to which this field is subjected" (Foucault 2002[1969]: 67). Uncovering the preconceptual is the task of what he calls "General Grammar" (Foucault 2002[1969]: 69). According to this set of 
methodological guidelines, analyses of the preconceptual require generalization of specific utterances, yet neither in terms of the generality of natural languages alone nor from a practically remote "horizon of ideality, placed, discovered, or established by a founding gesture" (Foucault 2002[1969]: 68-69; Foucault is referring to the Kantian transcendental $a$ priori). Instead, the preconceptual works predominantly on "the most 'superficial' level", the level of discourse itself, which is the locus of the emergence of concepts:

By that very fact, it is no longer necessary to appeal to the themes of an endlessly withdrawing origin and inexhaustible horizon: the organization of a group of rules in the practice of discourse, even if it does not constitute an event so easy to situate as a formulation or a discovery, may be determined, however, in the element of history; and if it is inexhaustible, it is by that very fact that the perfectly describable system that it constitutes takes account of a very considerable set of concepts and a very large number of transformations that affect both these concepts and their relations. Instead of outlining a horizon that rises from the depths of history and maintains itself through history, the 'preconceptual' thus described is, on the contrary, at the most 'superficial' level (at the level of discourse), the group of rules that in fact operate within it. (Foucault 2002 [1969]: 69)

The preconceptual is thus a performative precondition emerging from history, but not from a point indefinitely far away (like Gadamer's horizon of prejudice). And it is "inexhaustible", which means that it is strictly general. Foucault, quite unironically, called such discursive elements preceding intentional modification the "historical a priori":

Juxtaposed, these two words produce a rather startling effect [un effet un peu criant/screeching]; what I mean by the term is an a priori that is not a condition of validity for judgements, but a condition of reality for statements. It is not a question of rediscovering what might legitimize an assertion, but of freeing ["isoler", to isolate] the conditions of emergence of statements, the law of their coexistence with others, the specific form of their mode of being, the principles according to which they survive, become transformed, and disappear. An a priori not of truths that might never be said, or really given to experience; but the a priori of a history that is given, since it is that of things actually said. (Foucault 2002[1969]:143)

Over the following years, extralinguistic practices were increasingly included in the concept of discourse (Foucault 1981), so the preconceptual also had to move away from being limited to language. Power and its relation to Foucault's project of the "history of the present" (Foucault 1977: 31) took over several conceptual functions relating to the pre-intentional conditions of discourse. 
The relationship between Foucault's notion of power and Peirce's notion of habit has some affinities that have been examined by Andrew Garnar (2006). However, Garnar captures that relationship from a point of view where power results in the unilateral determination of habit. This is rooted in an understanding of power which Foucault shared in Discipline and Punish (Foucault 1977), but fails to include an important modification Foucault made to his concept of power after the publication of the first volume of The History of Sexuality. In the former, power was still captured in the metaphor of a two-dimensional foundational "network" (Foucault 1978: 95). A few years later, however, power was conceived of as a structure that is logically recursive:

In general terms, I believe that power is not built up out of 'wills' (individual or collective), nor is it derivable from interests. Power is constructed and functions on the basis of particular powers, myriad issues, myriad effects of power. It is this complex domain that must be studied. (Foucault 1980: 188)

This interactive conception of (strategic) power expresses Foucault's view that intentionality is a secondary effect in social interactions, while at the same time clarifying that power is foundational only when considered in conjunction with particular and diverse instalments of power. Power was thus complemented by a concept that can be regarded as a sort of obverse of habit, the dispositif. This "system of relations" is thought to mediate between "a thoroughly heterogeneous ensemble consisting of discourses, institutions, architectural forms, regulatory decisions, laws, administrative measures, scientific statements, philosophical, moral and philanthropic propositions - in short, the said as much as the unsaid" (Foucault 1980: 194). It also "responds to an urgent need" (Foucault 1980: 195), meaning that it has a strictly practical dimension that does not develop from intentionality, but from a pre-intentional dimension of (perceived) general necessity. Foucault thought that the concept of the dispositif would show "the nature of the connection that can exist between these heterogeneous elements" (Foucault 1980: 195) and that all these elements contributed to power as much as they were formed by power. Giorgio Agamben later showed that the concept of the dispositif does not merely include elements that are usually associated with fields such as politics, law, and education, where power typically resides, but is in fact also deeply engrained in the structure of everyday life:

Further expanding the already large class of Foucauldian apparatuses, I shall call an apparatus literally anything that has in some way the capacity to capture, orient, determine, intercept, model, control, or secure the gestures, behaviors, opinions, or discourses of living beings. Not only, therefore, prisons, madhouses, 
the panopticon, schools, confession, factories, disciplines, juridical measures, and so forth (whose connection with power is in a certain sense evident), but also the pen, writing, literature, philosophy, agriculture, cigarettes, navigation, computers, cellular telephones and - why not language itself, which is perhaps the most ancient of apparatuses - one in which thousands and thousands of years ago a primate inadvertently let himself be captured, probably without realizing the consequences that he was about to face. (Agamben 2009:14)

From the point of view of this expansion of the dispositif into everyday practice outside of the immediate influence of the larger assemblies of power, an essential connection between discourse, power and habit is beginning to show. All of these concepts are devised to represent the conservation of regularity (linguistic and/ or practical) and pass it on into the future. Habit, in this context, can function as an essential complement as it quite comprehensively represents, as a smallest common denominator, how "power relations can materially penetrate the body in depth, without depending even on the mediation of the subject's own representations" (Foucault 1980: 186). Foucault's later technical renditions of power were, of course, necessary to show that power is also, and especially, an effect that exists apart from individual and sovereign will, but its interface is still tied to practice that is adopted by and collectively shared between individuals. Thus, to know about power that is actually in effect means to know about the habits that anticipate individual action in relation to power. ${ }^{6}$

A comparison between habit and (Foucauldian) power intensifies what the Gadamer-Peirce comparison already indicated. It shows that Peirce's pragmaticistsemiotic notion of habit covers a wide range of effects that are investigated in cultural theory and that it is therefore possible (and productive) to render these areas of knowledge in terms of a general semiotic terminology. Conversely, this comparison also shows that a semiotic theory that claims to be universally applicable should ideally also be an interpretive semiotics that is self-aware of the historical conditions of emergence of the possible interpretations it describes. Signs interpreting signs, we are told by Peirce, will effect some practical response, whether that be an emotion, an individual action, or the formation of a concept. All of these types of responses, however, are always already premodified by a habitual response emerging from their practical historical conditions.

5 The English translation of Agamben's text follows the established English translation of 'dispositif as 'apparatus', conceived of perhaps under the influence of Althusser's notion of the 'state apparatus'.

6 See Feil (2019) for a complementary outlook on the relation particularly between Dewey's concept of habit and Foucault's concept of power in its transition from foundational to pragmatically recursive structures. 


\subsection{Blumenberg: preconceptuality through conceptuality}

The same conditions of emergence of statements that motivate Foucault's investigation into the preconceptual are, if at the outset seemingly unconcerned with "what is actually being said" (Foucault 2002[1969]: 143; see above), the focus of Hans Blumenberg's 'metaphorological' project. Blumenberg quite explicitly identifies a central aspect of Cartesian rationality as his motivation for engagement. In the Cartesian school of thought, he argues, metaphors "were an expression of the same précipitation regarding which Descartes, likewise in the first rule, states that it ought carefully to be avoided" (Blumenberg 2016[1960]: 2). Similarly with Peirce and his dual conception of prejudice and habit, a main point of focus of metaphorology is the way in which anticipatory elements of cognition received a somewhat negative connotation as ultimately avoidable precipitation in purely rationalistic models of cognition. Thus, the core of Blumenberg's thought on conceptuality is a theory that resists the rationalistic impulse which suggests that metaphors (and transitional tropes in general) are nothing but residual scrap language, are mere "rudiments on the path from mythos to logos" (Blumenberg 2016[1960]: 3). Blumenberg (2016[1960]: 3) confronts the scientistic fantasy of an ideal language with his notion of the 'absolute metaphor':

[M]etaphors can also [...] be foundational elements of philosophical language, 'translations' that resist being converted back into authenticity and logicality. If it could be shown that such translations, which would have to be called 'absolute metaphors', exist, then one of the essential tasks of conceptual history (in the thus expanded sense) would be to ascertain and analyze their conceptually irredeemable expressive function.

The basic idea of the 'absolute metaphor' is thus that conceptual thought is in many cases irrevocably preconditioned by the aid of some sort of apperceptive support. This metaphorical aspect inevitably welds with the concepts in such a way that it can be said to be the concept itself. This is not unlike Peirce's idea that a habit is the final logical interpretant (EP2: 418) and not merely represented by it. In both cases, some preconceptual entity ontologically frames the consequent concept. Moreover, Peirce's own view of metaphor is not too different from Blumenberg's:

Metaphysics has been said contemptuously to be a fabric of metaphors. But not only metaphysics, but logical and phaneroscopical concepts need to be clothed in such garments. For a pure idea without metaphor or other significant clothing is an onion without a peel. (EP2: 392) 
One major implication of Peirce's onion metaphor is that if one were to remove all imaginative support from a concept, the concept itself would be bound to disappear completely, just like an onion would disappear upon removal of the final layer. This is an approach to conceptuality not quite in line with what Peircean semiotics as logic, including his theory of metaphor (e.g. Anderson 1984; Hausman 1996), is generally associated with. However, as will become clear, it is an approach that has some resonance with his conception of habit.

After spending some 20 years working on several other projects as well as showing that 'absolute metaphors' do in fact exist, it dawned on Blumenberg that what he had had in mind in 1960 was not merely an auxiliary method for the history of concepts. Instead, 'metaphorology', in the later view, now is to be "no longer directed mainly toward the constitution of conceptuality but back toward the connections with the life-world as the constant motivating support (though one that cannot be constantly kept in view) of all theory" (Blumenberg 1997[1979]: 81).

Blumenberg's later view incorporates the idea that metaphor not only operates within language and structures the way we conceptualize things linguistically, but that conceptualizations are the result of practical necessities resulting from the 'normal' backdrop of the (life-)world and are mediated through metaphor (hence the support that theory receives from the life-world). This central idea of Blumenberg's much expanded general theory of 'nonconceptuality' (Unbegrifflichkeit) predates several now prominent theories of 'conceptual' and 'cognitive' metaphors by more than a decade. However, this basic similarity between conceptions of 'cognitive' and 'conceptual' metaphors and Blumenberg's notion also warrants a closer look at the Kantian framing of Blumenberg's theory of metaphor since Kant is the general precursor of most modern theories of schematicity. This comparison should then shed some light on what is at stake with nonconceptuality and make its relevance to the semiotics of habit clear.

Peirce's subdivision of iconic signs into three distinct modes, image, diagram and metaphor from the 1903 "Syllabus of certain topics of logic" (EP2: 274) is generally well known. Only slightly less well known is the precursor that these hypoicons are, perhaps unintentionally, modelled on, namely Immanuel Kant's subdivision of different types of intuitions into the reality of concepts, i.e. image/example, schema, and symbol. The idea of the schema has, of course, been extensively discussed in conjunction with Peirce's concept of the diagram (Stjernfelt 2007: 89-116, esp. 94). However, the point can be made that it is rather the Kantian concept of the symbol that provides the key to understanding the relation between habit and metaphor together with the idea of their respective hypothetical natures. 
From the outset, Kant's investigation into the analogical is moving beyond the linguistic, albeit often being rendered in examples from natural languages. In Critique of the Power of Judgment Kant claims and defends the idea that "beauty" is "a symbol of morality" (as goes the title of the chapter, Kant 2000[1790]: 225). By showing that it is possible to link entire sets of possible apperceptions to a set of moral actions, Kant demonstrates that his conception of symbolicity is indeed a universal property of understanding and its requisite power of judgment (cf. Friedlander 2015: 11), and is not limited to language alone:

All intuitions that are ascribed to concepts a priori are thus either schemata or symbols, the first of which contain direct, the second indirect presentations of the concept. The first do this demonstratively, the second by means of an analogy (for which empirical intuitions are also employed), in which the power of judgment performs a double task, first applying the concept to the object of a sensible intuition, and then, second, applying the mere rule of reflection on that intuition to an entirely different object, of which the first is only the symbol. Thus a monarchical state is represented by a body with a soul if it is ruled in accordance with laws internal to the people, but by a mere machine (like a handmill) if it is ruled by a single absolute will, but in both cases it is represented only symbolically. For between a despotic state and a handmill there is, of course, no similarity, but there is one between the rule for reflecting on both and their causality. (Kant 2000[1790]: 226)

It is quite obvious that, by describing the symbol, Kant had in mind something akin to metaphor, and precisely in the enhanced sense that Blumenberg came to realize with the idea of the unconceptual linking theory back to the lifeworld. Kantian symbolicity involves indirect presentation which relies on the (imaginative) power of judgment to apply the rule of a sensible intuition to an object outside the extension presented, which is thereby likened to the intuition on the basis of the rule alone. This, however, is also the basic mode of operation of habit, at least insofar as habit is, in fact, genuinely hypothetical and involves a certain amount of freedom not reducible to the schematic, where diagrams (as relational rules) are initially reproduced in a strictly identity-conserving way (NEM4: 318).

Blumenberg's metaphorology thus fashions preconceptuality in a way that is highly compatible with Peirce's theory of habit. Its focus on 'unconceptuality' resonates well with Peirce's idea that while preconceptuality is a pre-given of any cognitive process whatsoever, it is ultimately coordinated from a practically formed vantage point outside the immediate semiotic domain of that concept, i.e. habit. Conversely, if seen through the lens of Kant's theory of the symbol, it highlights an important detail regarding habituality in Peirce's semiotics: all transitional entities 
comparable to metaphors effect their significance (or, like habits, their modification of significance) through a process that does not directly replicate itself in the target domain, but merely its 'rule for reflection'. Just as metaphors do not create identity between 'tenor' and 'vehicle', that is to say, just like Achilles is not the tiger, an action or thought resulting from a habitually acquired rule does not follow the rule mechanically (see also West 2016: 227), but uses the rule to effectively 'enrich' a situation by vaguely suggesting that rule. Incidentally, understanding habit in such a way also lends a comprehensive conceptual framework and a semiotic outlook to Peirce's 'hypothesis' claim.

\section{4. "Reading" habit}

The purpose of this section is (1) to explore further the Peircean claim already mentioned in Section 1 that habit becomes "suggestible by sensations [...] by a psychical process having the form of hypothetic inference" (W8: 151) and (2) to reflect on the conditions of possibility of the "reading" habit.

Peirce's 'hypothesis' claim was first established in the 1892 "Law of Mind" where "hypothesis" is also further specified as "induction from qualities" (W8: 151). ${ }^{7}$ The whole process of habit-taking is specified as follows:

Thus, by induction, a number of sensations followed by one reaction become united under one general idea followed by the same reaction; while by the hypothetic process, a number of reactions called for by one occasion get united in a general idea which is called out by the same occasion. By deduction, the habit fulfills its function of calling out certain reactions on certain occasions. (W8: 151)

Peirce invokes the whole range of inferential modes at his disposal at the time to make the process clear. Induction synthesizes under one general idea any number of sensations tied to one reaction. Conversely, deduction analytically resolves established generalizations into further action for further occasions. The most revealing step involves the intermediate 'hypothetic process', where habit is in fact organized in an interesting way. The qualitative inductions underlying this process involve a capacity for judgment exercised on qualities, i.e. on "characters in comprehension (conjunctive terms, icons) [...]: we say that something which possesses a sample of the characters of a thing possesses all the characters of that thing (i.e.,

\footnotetext{
7 Note that 'hypothetic inference', specified as 'qualitative induction', should not be mistaken for what Peirce later properly called abduction. On the main difference, including a discussion of Peirce's own mistake, see, for example, Bellucci 2018: 2-6.
} 
is that thing whose characters it possesses)" (Bellucci 2018: 3). Hypothetic inference is thus responsible for decisions on the aptness of any given habit in relation to an occasion. And any such decision is based on hypothesis, which (among other things) explains why habits, as generals, can also come to bear on "inadequate" occasions.

If, for example, as a regular user of public transport, one is habituated to interpret certain minor cues from fellow passengers as signs of their desire to leave the vehicle, one may, over time, begin to anticipate these desires and behave accordingly (e.g. by picking up a bag previously placed on the floor, or by "preemptively" turning sideways so as to facilitate the passage of the fellow passenger). A habit (of unobstructiveness or consideration) has been formed by quantitative induction through the subsumption of a series of occasions successfully managed by way of a certain reaction. The habit thus formed is activated deductively when the appropriate occasion arises. However, cues remarkably similar to those actually habituated can trigger the habit in spite of the actual adequacy of the habit. A fellow passenger may, after a minute-long silence, turn towards the habit-bearer, but not to ask her to move, but to ask for the time. Or, conversely, some uneasy twitching of a fellow passenger may be taken as a sign that she is deeply involved in the music playing in her headphones, while in fact she is getting ready to stand up from her seat to get off at the next station. In every case, habit depends on some low-key interpretation of similarity between sensation, rule and occasion to determine whether the particular occasion fits the rule or general idea. In any case, however, an occasion will establish the frame of reference for subsequent action or thought and may even predetermine the interpretation of sensations deemed relevant.

The necessary mediation performed by such an intermediate step of hypothetic inference shows that there is no strict identity between one clearly defined habit and one clearly defined occasion, even though many habits are firmly tied to certain sensations and occasions in such a way that they seem almost mechanical. For a habit actually to become useful, it must become general. Still, generality is not identity in actuality, and it always involves some type of premeditated form of judgment. This, in turn, is the precondition for Peirce's idea that the presence of habit is not necessarily informative of some definitive meaning: "No Symbol", writes Peirce in the "Prolegomena for an Apology for Pragmatism" (1906), "can do more than apply a 'rule of thumb' resting as it does entirely on Habit (including under this term natural disposition); and a Habit is no evidence" (NEM4: 317).

This poses a conundrum: habit is an essential component in the generation and interpretation of meaning, at least as far as vaguely symbolic meaning is concerned. Yet there is no definitive way of fixing meaning retroactively, since it must be derived from habit, and habit, not only in its formation but also in its application, involves an element of non-necessary inference. 
Moreover, the fact that habit is "no evidence" precisely means that no definitive clarity can be derived from stating that "this is a habit for that". Even knowing that a certain habit is in operation will not with absolute certainty allow the person aware of this to predict clearly what the actual effect of every possible application of that habit will be. From the point of view of clarity and distinctness, it seems that habit, while being an all-pervasive component of symbolic life, is a rather fruitless point of interpretive focus. Habit lends guidance and structure to innumerable new interpretations but is itself very hard to pin down.

Anticipating anticipation is therefore imprecise precisely because of this nonevidential character that, by analogy, links rule and qualitative evaluation on a provisional basis. Perfect clarity in a Cartesian sense is simply precluded. This may seem counterintuitive, given that actions derived from habit often appear as very clear-cut cases. However, this is perhaps more a testimony to the fact that reasonably formed hypotheses based on the prior experience of rules are generally not unreliable. And it is also true that habit does in fact enhance any given situation by linking it to the subject's capacities (as, for instance, the reasonably formed habit of consideration in the example above). Still, neither does any occurrence of a habitual response necessarily suggest a certain type of situation, nor does any particular type of situation necessarily suggest a corresponding habit. This entails that, just as a seemingly arbitrary expression emerges from repeated success in the application of one metaphor, a habit can become uncoupled from the context of its inductive formation and begin to lead a more general "life". In the "Habit" lecture (1898) published in Reasoning and the Logic of Things, which, among other things, set out to defend the distinctness of several modes of association by resemblance, Peirce makes a remark in that regard:

But the repeated occurrence of a general idea and the experience of its utility, results in the formation or strengthening of that habit which is the conception; or if the conception is already a habit thoroughly compacted, the general idea is the mark of the habit. (RLT 234)

General ideas which represent the expectation of certain relations have the capacity to modify and even to constitute habit, ideally by confirmation from experience. And, as Peirce put it in the Minute Logic (1902), the imagination, too, is capable of forming habits (CP 2.148). This means that habits are not only activated internally by hypothetic inference, but are also transformed, not by the brute force of experience alone, but also through internal reflection on the possible association of rules (as diagrams). This is the case simply because they are intrinsically linked to general ideas which leave potentially traceable marks on cognition. Habit 
therefore represents a type of generality not restricted to discrete formations, but as strict continuity in the sense that it involves a "relation or relations of contiguity", which implies the possibility of "a passage from one part to a contiguous part" (CP 7.535 fn6). Habits realized in individual bearers are linked to each other by bordering on each other in a continuum that emerges over time.

Commenting on the task of "reading" habits is motivated by the prior assessment of habit's essential connection to conceptualization and its resulting coordinative power which links its bearers to their environments. As Peirce expressed it in the "Pragmatism" manuscript, "the most perfect account of a concept that words can convey will consist in a description of the habit which that concept is calculated to produce" (EP2: 418). However, considering the phenomenal historicity of habit itself, attention must shift away from the mere confirmation of present habit in the future when "reading" habit. Before admitting his perplexity regarding a procedure of generalizing "experience which however exhibits singulars only" (EP2: 550 , see above), Peirce had already elaborated on the idea of "future confirmation" in an earlier draft of the "Pragmatism" manuscript:

But how otherwise can a habit be described than by a description of the kind of action to which it gives rise, with the specification of the conditions and of the motive? (EP2: 418)

Knowing well that this question was meant to be merely rhetorical, there is some merit in taking it as an actual question and elaborating upon its implications. Especially given the fact that the type of habit identified by this type of specification does not do justice to precisely what Peirce's refined concept of habit actually involves, an attempt at explicating the 'otherwise' in the question is justified. Following Peirce's suggestion, one would describe a supposed habit by deducing from it the coordinates for a possible type of thought or action under possible conditions and to a possible end. Accordingly, one would set up an experiment for future confirmation. If we assume habit $\mathrm{H}$ in conjunction with action $\mathrm{A}$, conditions $\mathrm{C}$ and motive $\mathrm{M}$, and if we then detect the occurrence of action $\mathrm{A}$, conditions $\mathrm{C}$ and motive $\mathrm{M}$ in some observation, we infer that habit $\mathrm{H}$ is in operation. However, this purely empirical verification is suitable only for the most clear-cut of cases and in itself involves only a very basic abductory step.

In order actually to assume the existence of a habit in the first place, we must already have detected some type of regularity, thus we must have performed some type of "reading". The 'general mark'-idea metaphorically suggests that "reading" is a valid operation, at least in theory, given the essential connection between 
concepts and their anticipatory content and practice. It is therefore perhaps actually necessary to start with the 1898 idea that "a general idea is the mark of habit" (see above) and combine that premise with the general condition, established in the experimental setup, that some sort of temporal distance is required between habit-formation and -modification and the actual occurrence of a habit in the empirical world. Not every general idea is automatically the mark of a habit; this is the case only if the habit has been, as Peirce expressed it, "thoroughly compacted" (RLT: 234). This compacting, of course, entails generalization to a degree that makes the habit "lean" enough to detach itself from its conditions and motives of origin. The primary vehicle of this process, as we have seen (particularly in the Blumenberg/Kant section), is the skeletal rule manifest in the diagram (also Vitral 2019 141-144). And this rule-component of habit can also be clearly stated regardless of the specifics of its application.

The task of "reading" a habit involves, as Peirce put it in the previously quoted footnote to the last draft of "Pragmatism", the requirement that "our minds must generalize these" (see above). Generalization in that sense includes hypothetically moving back in time and looking at precursors to the ideas that are suspected to serve as marks of a habit, specifying the more general conditions and motives and comparing them to the present. In short, reading a habit, that is, forming a systematic hypothesis on the expectations which a concept transports, requires from the very outset a historical perspective, a practical orientation, and a sensibility for the reflexive transmission of rules. It requires the construction (or rather the reconstruction) of trajectories of anticipation through time according to the ways in which rules embodied in habits are successfully adopted. It is through the identification of these trajectories that habits actually in operation are more comprehensively understood and made accessible to reflection, modification, and change.

\section{Concluding remarks}

In "Prospects for a theory of nonconceptuality", Blumenberg wrote:

That the world is a book in which one could read or, after laborious deciphering, might finally be able to read is a metaphorical expectation concerning the nature of experience. [...] The 'book of nature' is not merely a subject for topos researchers to collect citations on. It is also an orientation for inquiring back from the actual status of the theoretical attitude toward the world to the giving of meaning, in the life-world, that underlies it. It would be pure romanticism to do this with the intention of reestablishing the position of the reader of the book of nature. (Blumenberg 1997[1979]: 86) 
Being able to read the world is, as Blumenberg puts it, an expectation prefigured by the 'book-of-life'-metaphor. The same is equally true for the idea that habits can be read - there is no use in trying to resist this metaphor. Likewise, it seems, 'clarity' and 'distinctness' are expectations, perhaps not merely metaphorical (prefigured for example by 'light' as a metaphor for truth in philosophical discourse, cf. Blumenberg 1993) but habitual in the sense that they structure expectations concerning accepted modes of inquiry. Clarity, for example, can be schematized as the unperturbed line and distinctness as a circle that differentiates between the inside and the outside. The impossibility of reclaiming the lost vantage point of perfect clarity and distinctness may be a disappointing prospect for bearers of habits of clarity and distinctness. However, it is also a precondition of the possibility for change. If there is no interference in direction and no permeability between opposites, there is simply no room for variation.

Considered in relation to its own genesis and in comparison with concepts fashioned from the same cloth of resistance to Cartesianism, it seems obvious that habit is an important key term for semiotics, not only because it explains several background operations of sign action, but also especially because it explains these background operations in relation to key terms in other areas of research. The concept of habit provides points of insertion for semiotic inquiry into disciplines such as hermeneutics, the sociology and history of power and conceptual history. It shows that interdisciplinary cross-fertilization between semiotics and other areas of inquiry is productive not only in the sense that it is possible to redescribe one discipline from the perspective of another (e.g. 'the semiotics of history' or 'the history of semiotics'), but that various disciplines can be productively redescribed as fundamentally co-extensive in regard to some of their basic disciplinary assumptions. Employing a Peircean expression from the late "Habituesence" manuscript, all inquiry shares "essentially the same interpretive consciousness in every case" (MS 930: 32-33). This central semiotic tenet is realized, for example, through the general semiotics of Peirce, but it appears to be the case especially also in comparison with other fields of inquiry. Habit is a key term of Peircean semiotics, but its scope and value as an interpretive demand regarding the historicization of the anticipatory field of preconceptuality only comes to its full potential when confronted with that demand from outside of Peircean semiotics. ${ }^{8}$

8 This paper is an expanded version of a presentation given at the 11th Conference of the Nordic Association for Semiotic Studies in Stavanger on 13 June 2019. The author is grateful for the financial support received from the University of Augsburg's Young Researchers Travel Scholarship Program for the attendance of this conference. The author would also like to thank Aleksandar Feodorov for his helpful comments on the final draft of this paper and Kerstin Bachmeier for her invaluable linguistic support. 


\section{References}

Anderson, Douglas 1984. Peirce on metaphor. Transactions of the Charles S. Peirce Society 20(4): 453-468.

CP = Peirce, Charles S. 1931-1958. Collected Papers of Charles Sanders Peirce. Cambridge: Harvard University Press. (Vols. 1-6, Hartshorne, Charles; Weiss, Paul, eds., 19311935; vols. 7-8, Burks, Arthur W., ed., 1958.) [In-text references are to CP, followed by volume and paragraph numbers.]

Agamben, Giorgio 2009. "What is an Apparatus?" and Other Essays. (Kishik, David; Pedatella, Stefan, trans.) Stanford: Stanford University Press.

Bellucci, Francesco 2018. Eco and Peirce on abduction. European Journal of Pragmatism and American Philosophy 10(1):1-20. https://doi.org/10.4000/ejpap.1122

Bergman, Mats 2012. Improving our habits: Peirce and meliorism. In: De Waal, Cornelis; Skowroński, Krzysztof Piotr (eds.), The Normative Thought of Charles Sanders Peirce. (1st ed.) New York: Fordham University Press, 125-148.

Bergman, Mats 2016. Beyond explication: Meaning and habit-change in Peirce's pragmatism. In: West, Donna E.; Anderson, Myrdene (eds.), Consensus on Peirce's Concept of Habit. Cham: Springer International Publishing, 171-197. https://doi.org/10.1007/9783-319-45920-2_11

Bisanz, Elize; Cunningham, Scott 2016. Habit as a law of mind: A Peircean approach to habit in cultural and mental phenomena. In: West, Donna E.; Anderson, Myrdene (eds.), Consensus on Peirce's Concept of Habit. Cham: Springer International Publishing, 401-419. https://doi.org/10.1007/978-3-319-45920-2_22

Blumenberg, Hans 1993. Light as a metaphor for truth: At the preliminary stage of philosophical concept formation. In: Levin, David Michael (ed.), Modernity and the Hegemony of Vision. Berkeley: University of California Press, 30-62.

Blumenberg, Hans 1997[1979]. Prospect for a theory of nonconceptuality. In: Shipwreck with Spectator: Paradigm for a Metaphor of Existence. Cambridge: MIT Press, 81-102.

Blumenberg, Hans 2016[1960]. Paradigms for a Metaphorology. (Savage, Robert, trans.) Ithaka: Cornell University Press.

Cannizzaro, Sara; Anderson, Myrdene 2016. Culture as habit, habit as culture: Instinct, habituescence, addiction. In: West, Donna E.; Anderson, Myrdene (eds.), Consensus on Peirce's Concept of Habit. Cham: Springer International Publishing, 315-339. https:// doi.org/10.1007/978-3-319-45920-2_18

CP = Peirce, Charles S. 1931-1958. Collected Papers of Charles Sanders Peirce. Cambridge: Harvard University Press. (Vols. 1-6, Hartshorne, Charles; Weiss, Paul, eds., 19311935; vols. 7-8, Burks, Arthur W., ed., 1958.) [In-text references are to CP, followed by volume and paragraph numbers.]

Descartes, René 2006[1637]. A Discourse on the Method of Correctly Conducting One's Reason and Seeking Truth in the Sciences. (Maclean, Ian, trans.). Oxford: Oxford University Press.

Dewey, John 2008[1992]. Human Nature and Conduct. (Boydston, Jo Ann, ed.) Carbondale: Southern Illinois University Press.

Dilthey, Wilhelm 2002[1910]. The Formation of the Historical World in the Human Sciences. (Makreel, Rudolf A.; Rodi, Frithjof, eds.) Princeton: Princeton University Press. 
Dreyfus, Hubert L; Rainbow, Paul 1983. Michel Foucault: Beyond Structuralism and Hermeneutics. (2nd ed.) Chicago: University of Chicago Press. https://doi.org/10.7208/ chicago/9780226154534.001.0001

EP2 = Peirce, Charles Sanders 1998. The Essential Peirce. Volume 2: Selected Philosophical Writings (1893-1913). (The Peirce Edition Project, eds.) Bloomington: Indiana University Press. [In-text references are to EP2, followed by page numbers.]

Fehér, István 2016. Prejudice and pre-understanding. In: Keane, Niall; Lawn, Chris (eds.), The Blackwell Companion to Hermeneutics. Chichester: Wiley-Blackwell, 280-288. https://doi.org/10.1002/9781118529812.ch32

Feil, Sebastian 2019. The power of habit. In: Feodorov, Aleksandar; Mladenov, Ivan (eds.), Non/Cognate Approaches - Relation and Representation. Sofia: Paradigma Publishing, 85-102.

Feil, Sebastian; Olteanu, Alin 2018. Abduction, hermeneutics, and the interpretation of interpretations. Human Areas 1(2): 206-222. https://doi.org/10.1007/s42087-0180013-y

Feodorov, Aleksandar 2017. Habit beyond psychology: The evolution of the concept. European Journal of Pragmatism and American Philosophy 9(1): s.p. https://doi. org/10.4000/ejpap.1007

Foucault, Michel 1977. Discipline and Punish: The Birth of the Prison. (Sheridan, Alan, trans.) New York: Vintage Books.

Foucault, Michel 1978. The History of Sexuality. Vol. I: An Introduction. (Hurley, Robert, trans.) New York: Pantheon Books.

Foucault, Michel 1980. Power/Knowledge: Selected Interviews and Other Writings, 19721977. (Gordon, Colin, ed.) New York: Pantheon Books.

Foucault, Michel 1981. The order of discourse. In: Young, Robert (ed.), Untying the Text: A Post-Structuralist Reader. Boston: Routledge \& Kegan Paul, 51-78.

Foucault, Michel 2002: Archaeology of Knowledge. (Smith, Sheridan; Mark, Alan, trans.) London: Harvard University Press.

Friedlander, Eli 2015. Expressions of Judgement: An Essay on Kant's Aesthetics. Cambridge: Harvard University Press.

Gadamer, Hans-Georg 2013[1960]. Truth and Method. (Weinsheimer, Joel; Marshall, Donald G., trans.) London: Bloomsbury.

Garnar, Andrew 2006. Power, action, signs: Between Peirce and Foucault. Transactions of the Charles S. Peirce Society 4 (3): 347-366. https://doi.org/10.1353/csp.2006.0029

Hausman, Carl 1996. Peirce and the interaction view of metaphor. In: Colapietro, Vincent; Olshewsky, Thomas (eds.), Peirce's Doctrine of Signs: Theory, Applications, and Connections. Berlin: Mouton de Gruyter, 193-203. https://doi.org/10.1515/ 9783110873450.193

Kant, Immanuel 2000[1790] Critique of Power of Judgement. (Matthews, Eric; Guyer, Paul, trans.; Guyer, Paul, ed.) Cambridge: Cambridge University Press. https://doi. org/10.1017/CBO9780511804656

Lalor, Brendan 1997. The classification of Peirce's interpretants. Semiotica 11(1-2): 31-40. https://doi.org/10.1515/semi.1997.114.1-2.31

MS = Peirce, Charles Sanders. Unpublished manuscripts. Copies from Peirce Edition Project of Indiana University - Purdue University, Indianapolis. [In-text references are to MS, followed by manuscript number and page numbers.] 
NEM4 = Peirce, Charles Sanders 1976. The New Elements of Mathematics. Volume 4 Mathematical Philosophy. (Eisele, Carolyn, ed.) The Hague: Mouton. [In-text references are to NEM4, followed by page numbers.]

Nöth, Winfried 2010. The criterion of habit in Peirce's definitions of the symbol. Transactions of the Charles S. Peirce Society 46(1): 82-93. https://doi.org/10.2979/ tra.2010.46.1.82

Nöth, Winfried 2016. Habit, habit change, and the habit of habit chance according to Peirce. In: West, Donna E.; Anderson, Myrdene (eds.), Consensus on Peirce's Conception of Habits. Cham: Springer International Publishing, 35-63. https://doi. org/10.1007/978-3-319-45920-2_3

Odenstedt, Anders 2003. Gadamer on context-dependence. The Review of Metaphysics 57: 75-104.

RLT = Peirce, Charles Sanders 1992. Reasoning and the Logic of Things: The Cambridge Conferences Lectures of 1898. (Ketner, Kenneth Laine; Putnam, Hilary, eds.) Bloomington: Indiana University Press. [In-text references are to RLT, followed page numbers.]

Santaella, Lucia 2016. The originality and relevance of Peirce's concept of habit. In: West, Donna E.; Anderson, Myrdene (eds.), Consensus on Peirce's Concept of Habit. Cham: Springer International Publishing, 153-170. https://doi.org/10.1007/978-3-319-459202_10

Short, Thomas Lloyd 2007. Peirce's Theory of Signs. Cambridge: Cambridge University Press. https://doi.org/10.1017/CBO9780511498350

Stjernfelt, Frederik 2007. Diagrammatology: An Investigation on the Borderlines of Phenomenology, Ontology, and Semiotics. Dordrecht: Springer.

Vitral, Letícia 2019. Diagrams and the crossroads between aesthetics and epistemology. In: Feodorov, Aleksandar; Mladenov, Ivan (eds.), Non/Cognate Approaches - Relation and Representation. Sofia: Paradigma Publishing, 127-150.

West, Donna 2016. Indexical scaffolds to habit-formation. In: West, Donna E.; Anderson, Myrdene (eds.), Consensus on Peirce's Concept of Habit. Cham: Springer International Publishing, 215-240. https://doi.org/10.1007/978-3-319-45920-2_13

W2 $=$ Peirce, Charles Sanders 1982. Writings of Charles S. Peirce: A Chronological Edition . Volume 2. (Fisch, Max Harold; Kloesel, Christian J. W.; Moore, Edward C., eds.) Bloomington: Indiana University Press. [In-text references are to W2, followed by page numbers.]

W3 = Peirce, Charles Sanders 1986. Writings of Charles S. Peirce: A Chronological Edition. Volume 3. (Fisch, Max Harold; Kloesel, Christian J. W; Houser, Nathan, eds.) Bloomington: Indiana University Press. [In-text references are to W3, followed by page numbers.]

W8 = Peirce, Charles Sanders; Houser, Nathan; De Tienne, André 2010. Writings of Charles S. Peirce: A Chronological Edition. Volume 8. Bloomington: Indiana University Press. [In-text references are to $\mathrm{W} 8$, followed by page numbers.] 


\section{Траектории предвидения: преконцептуальность и задача «чтения» привычки}

Статья характеризует концепцию привычки (habit) Пирса как важный вклад в концепцию пирсовской преконцептуальности. Рассматриваются, во-первых, ее функции в знаковом процессе, и, во-вторых, связь с другими концепциями преконцептуальности в исследованиях культуры. Понятие предрассудка Ганса-Георга Гадамера, понятия преконцептуальности и диспозитива Мишеля Фуко, а также понятие метафоры Ганса Блюменберга - все они имеют сходства с некоторыми ключевыми характеристиками понятия привычки Пирса. В этом сравнении также становится понятно, что в представлении о пирсовском понятии привычки не указываются некоторые элементы: хотя любое истолкование имплицитно зависит от теории историчности и соответствующих правил, эти аспекты возникают только в сравнении с теориями, которые эксплицитно сосредоточены именно на них.

Другой вопрос, затронутый в контексте такого сравнения, заключается в актуальности привычки для теорий концептуальности. Основная часть координирующей силы концепта заключается в связанных с ним привычках. Тем не менее, на данный момент отсутствуют систематические исследования относительно цельного понимания реальных привычек. Поэтому в статье предпринимается попытка исправить эту ситуацию, разрабатывая аспекты пирсовской теории привычки, имеющие отношение к теории «чтения привычки» (reading habit).

\section{Etteaimamise trajektoorid: prekontseptuaalsus ja harjumuse lugemise ülesanne.}

Artiklis iseloomustatakse Peirce'i harjumuse mõistet kui olulist panust Peirce’i prekontseptuaalsuse mõistesse, esmalt seoses selle funktsiooniga märgiprotsessis ja teiseks seoses muude kultuuriuuringutes esinevate prekontseptuaalsuse mõistetega. Nii Hans-Georg Gadameri eelarvamuse mõistel, Michel Foucault' arusaamadel prekontseptuaalsusest ja 'dispositif ist kui ka Hans Blumenbergi metafoorikontseptsioonil on kõigil võtmetähenduslikke ühiseid omadusi Peirce'i harjumuse mõistega. Samas võrdluses tuleb esile ka tõik, et Peirce'i harjumuse mõistet puudutavast praegusest diskursusest puuduvad teatud elemendid: kuigi igasugune harjumuse mõiste tõlgendamine sõltub implitsiitselt ajaloolisuse teooriast ning seosest reeglitega, tulevad need aspektid ilmsiks üksnes võrreldes teooriatega, mis neile eksplitsiitsemalt keskenduvad.

Veel üks küsimus, mis sellise kõrvutuse kontekstis tekib, on harjumuse olulisus kontseptuaalsuse teooriate jaoks. Suur osa mõistete koordineerivast jõust peitub mõistega seonduvates harjumustes. Ent tegelike harjumuste konkreetsemaks muutmise võimalikkust ei ole süstemaatiliselt uuritud. Seega püütakse seda olukorda parandada, käsitledes põhjalikumalt Peirce harjumusteooria neid aspekte, mis on olulised "harjumuse lugemise" teooria jaoks, ning pakkudes visandit sellisest teooriast. 